\title{
Create10 - The interaction design conference
}

\author{
Edinburgh Napier University, UK \\ 30 June - 2 July 2010
}

Editors:

Oli Mival

John Bonner

Michael Smyth

Shaleph O'Neill 


\section{Abstract}

The annual Create conference centres on interaction design, a young discipline with roots in humancomputer interaction, ergonomics, product and graphic design, multi-media and art. An interaction designer is a difficult person to pigeonhole and can be found in mobile phone companies, consumer product manufacturers, design consultancies, as a single practitioner, or within academic computing and design departments.

After three very successful years at the BCS offices in London's Covent Garden, the Create conference moved north to Edinburgh Napier University, inspiring the broad theme of 'transitions'. The move to the university's city centre venue allowed the conference to expand and also provided an opportunity to showcase examples of design work from students and established practitioners.

The conference covers theoretical and research perspectives on the process of design innovation and approaches to creativity in $\mathrm{HCl}$; how human factors can be integrated within a creative design process, methods that encourage creativity in interaction design, and the challenges of working in multi-disciplinary teams.

As well as presentation of academic research and student work, the conference will provide real learning opportunities through hands-on workshops, case studies and demonstrations. We also welcome theoretical and research perspectives on the process of design innovation and approaches to creativity in $\mathrm{HCl}$; how human factors can be integrated within a creative design process, methods that encourage creativity in interaction design, and the challenges of working in multi-disciplinary teams. 


\section{Editors}

Oli Mival is a Senior Research Fellow at Edinburgh Napier University's Centre for Interaction Design. His PhD examined the impact of technology on real world creative practice. In 2003 Oli founded and managed Those Media Guys, a film and media production company based in Edinburgh whose clients included Channel 4, BBC, RBS and Warner Bros.

Returning to academia, in 2006 he oversaw the interaction design elements of the $€ 15 \mathrm{~m}$ EU funded Companions project. In 2009 he worked on the design, development and construction of the Interactive Collaborative Environment, a major technology showcase and research base for Edinburgh Napier University. He is now Director of the Future Interactions Network which explores the design, development and impact of future and emerging technologies on real world people, practice and places www.futureinteractions.net

John Bonner has over 20 years experience gained in the fields of human factors, product and interaction design in both academic and commercial environments. After graduating with a degree in Ergonomics from Loughborough University, he became a research associate at HUSAT Research Institute. As an ergonomics design consultant he worked on a wide range of projects including usability studies, interface design and physiological studies. On returning to academia, John taught ergonomics and industrial design at Teesside University. Having moved to Huddersfield University in 1999, he completed a PhD in interaction design from Loughborough University. With research interests in interaction design and ubiquitous computing he set up a small research group known as live:lab. www.livelab.hud.ac.uk

Michael Smyth is a Reader in the Centre for Interaction Design, Edinburgh Napier University, UK. He has worked in the fields of Human Computer Interaction and Interaction Design since 1987 and during that period has published over 50 academic papers in refereed journals, books and conferences. In addition he has had interactive installations exhibited at both UK and international conferences and arts \& design festivals. He is co-editor of the book entitled Digital

Blur: creative practice at the boundaries of architecture, design and art, Libri Publishing.

Shaleph O'Neill is the Course Director for the Interactive Media Design programme at the University of Dundee. He initially trained in fine art, as a sculptor, where his interest in the communication of meaning lead to the production and exhibition of artwork that explored the use of semiotics. In 2001, he began a $\mathrm{PhD}$ at Napier University under Prof. David Benyon's supervision, which applied his artistic background and interest in semiotics to the issues of user interface design. He has worked as a research assistant on the EU funded BENOGO project in the Future and Emerging Technologies programme of Framework 5. Investigating the issue of 'presence' in virtual environments, he developed a phenomenological understanding of how to communicate a sense of 'place' within virtual environments.

www.computing.dundee.ac.uk 


\section{Papers:}

\section{Keynotes}

Mika 'Lumi' Tuomala Inside Out: Dialogical Design of Digital Drama http://dx.doi.org/10.14236/ewic/CREATE2010.1

Ernest Edmonds The Art of Interaction http://dx.doi.org/10.14236/ewic/CREATE2010.2

\section{Full Papers}

Tero Heikkinen and Jussi Mikkonen Developing a physical colour input device for studying digital sketching in design http://dx.doi.org/10.14236/ewic/CREATE2010.3

Sophia Atzeni, Annemiek van Drunen, Aljosja Jacobs and Dirk Verhagen A New Approach to Brainstorming: Multitouch Brainstorming http://dx.doi.org/10.14236/ewic/CREATE2010.4

Øystein Veland and Gisle Andresen Focusing design and staging design conversations in complex settings through 'design documentary' filmmaking http://dx.doi.org/10.14236/ewic/CREATE2010.5

Naveen Bagalkot and Tomas Sokoler Magic Mirror: Exploring designing for transitions as they play out in everyday physical rehabilitation $\quad$ http://dx.doi.org/10.14236/ewic/CREATE2010.6

Kumiyo Nakakoji, Yasuhiro Yamamoto and Yasuharu Koike Toward Principles for Visual Interaction Design for Communicating Weight by using Pseudo-Haptic Feedback http://dx.doi.org/10.14236/ewic/CREATE2010.7

Kai Kasugai, Martina Ziefle, Carsten Röcker and Peter Russell Creating Spatio-Temporal Contiguities Between Real and Virtual Rooms in an Assistive Living Environment http://dx.doi.org/10.14236/ewic/CREATE2010.8

David England Art and Interaction: Some Reflections http://dx.doi.org/10.14236/ewic/CREATE2010.9

Dave Wood Moving Across the Boundaries: Visual Communication Repositioned in Support of Interaction Design $\quad$ http://dx.doi.org/10.14236/ewic/CREATE2010.10

Daniel Fallman and Erik Stolterman Establishing Criteria of Rigor and Relevance in Interaction Design Research $\quad$ http://dx.doi.org/10.14236/ewic/CREATE2010.11 


\title{
Short Papers, Workshops and Case Studies
}

\author{
Wen Huei Chou, Ni Jia Yang and Shih Nung Cheng Multimedia Design in the Implementation of \\ Cultural Research http://dx.doi.org/10.14236/ewic/CREATE2010.12 \\ Victor Kaptelinin $\quad$ Facing the dark side of life: The challenge of addressing users' fears in \\ interaction design $\quad$ http://dx.doi.org/10.14236/ewic/CREATE2010.13
}

Shaun McWhinnie and Shaleph O'Neill Describing Creativity with Card Sorting and Processing http://dx.doi.org/10.14236/ewic/CREATE2010.14

Satoru Tokuhisa and Yusuke Kamiyama The World is Canvas: A Painting Application for Children based on the Social Constructivism System http://dx.doi.org/10.14236/ewic/CREATE2010.15

Sarah Kettley, Tina Downes, Karen Harrigan and Martha Glazzard Fit for purpose? Pattern cutting and seams in wearables development http://dx.doi.org/10.14236/ewic/CREATE2010.16

Néna Roa Sëiler and Ariadna Benítez Saucedo Virtual Mirror http://dx.doi.org/10.14236/ewic/CREATE2010.17

Max Zabramny Designing Digital Experiences in an Analog World http://dx.doi.org/10.14236/ewic/CREATE2010.18

Licia Calvi and Paul Buchanan A Case on Generative Art: Digital Poetry http://dx.doi.org/10.14236/ewic/CREATE2010.19

Jonathan Rez Rethinking Retail Experience http://dx.doi.org/10.14236/ewic/CREATE2010.20

Jim Wood Using participatory design methods with ubiquitous computing technologies http://dx.doi.org/10.14236/ewic/CREATE2010.21

Jonathan Hamilton Dipping 1200 toes into the pool of immersive interaction design http://dx.doi.org/10.14236/ewic/CREATE2010.22

Elena Nazzi, Naveen Bagalkot and Tomas Sokoler Twitterido: designing for transitions in communicating through doing http://dx.doi.org/10.14236/ewic/CREATE2010.23

Dries De Roeck, Jan Derboven, Mathijs Verstraete and David Geerts Bridging the Real and the Virtual: Low and High Fidelity Tabletop Prototyping http://dx.doi.org/10.14236/ewic/CREATE2010.24

Chris Speed, Maria Burke, Andrew Hudson-Smith, Angelina Karpovich, Simone O'Callaghan and Morna Simpson Internet of Old Things http://dx.doi.org/10.14236/ewic/CREATE2010.25

Clare J. Hooper and David E. Millard Supporting Transitions with Creative Software Engineering http://dx.doi.org/10.14236/ewic/CREATE2010.26 


\section{Posters}

Dan Wandrey, Kyle Larkin and Ryan Spicer Community Futures: Web Tools to Empower Public Participation in Urban Development http://dx.doi.org/10.14236/ewic/CREATE2010.27

Dr Noel Waite Design History Exhibitions: The critical interaction of people and practice http://dx.doi.org/10.14236/ewic/CREATE2010.28

Lawrence George Giles Invisible Signs http://dx.doi.org/10.14236/ewic/CREATE2010.29

Blanca Acuña Designing a Digital Interface for Museum-Interpretation http://dx.doi.org/10.14236/ewic/CREATE2010.30

Devabrata Paramanik Hybrid Print Systems: Creating printed textile designs through Motion capture, Visual programming language and Digital inkject printing technology http://dx.doi.org/10.14236/ewic/CREATE2010.31

Hayeon Yoo Poetic Communication - Compass Phone http://dx.doi.org/10.14236/ewic/CREATE2010.32

Mariza Dima, John Lee and Mark WrightHapty: A haptically augmented animation tool http://dx.doi.org/10.14236/ewic/CREATE2010.33

Florian Weingarten, Marco Blumendorf and Sahin Albayrak Conveying Multimodal Interaction possibilities through the use of Appearances http://dx.doi.org/10.14236/ewic/CREATE2010.34

Scott Burns LiveLink, interactive newspaper content http://dx.doi.org/10.14236/ewic/CREATE2010.35

Pablo Prieto Exploring New Intuitive Interfaces for a Natural Design Process http://dx.doi.org/10.14236/ewic/CREATE2010.36

Aikaterini Antonopoulou Living in Second Life versus Acting in Flash Mob http://dx.doi.org/10.14236/ewic/CREATE2010.37

Andrew O'DowdInvisible Boundaries, visualising our personal social spaces http://dx.doi.org/10.14236/ewic/CREATE2010.38 